\title{
Fiscal Stimulus and Unemployment Dynamics
}

\author{
Chun-Hung Kuo \\ International University of Japan
}

\author{
Hiroaki Miyamoto* \\ The University of Tokyo
}

April 22, 2014

\begin{abstract}
Focusing on both hiring and firing margins, this paper revisits effects of fiscal expansion on unemployment. We provide evidence that an increase in government spending increases the job finding rate and reduces the separation rate, lowering unemployment in the U.S. by using a structural VAR model. We then develop a DSGE model with search frictions where job separation is endogenously determined. Our model can capture the empirical pattern of responses of the job finding, separation, and unemployment rates to a government spending shock. We also demonstrate that model's predictions are in contrast with earlier studies that assume exogenous separation.
\end{abstract}

JEL Classification: E24; E62; J64

Keywords: Fiscal Policy; Unemployment; Labor market; Search and matching; Endogenous separation

*Hiroaki Miyamoto (Corresponding author). Mailing address: The University of Tokyo, 7-3-1 Hongo, Bunkyo-ku, Tokyo 113-0033 JAPAN. Tel. +81-3-5841-1411. E-mail: miyamoto@pp.u-tokyo.ac.jp 


\section{Introduction}

Recently, a number of studies examine effects of fiscal expansion on unemployment in dynamic stochastic general equilibrium (DSGE) models (Yuan and Li, 2000; Monacelli et al., 2010; Campolmi et al., 2011; Brückner and Pappa, 2012). They incorporate labor search frictions into an otherwise standard DSGE model and study effects of fiscal stimuli in the form of government spending and hiring subsidies on the economy. One of common features of these studies is exogenous job separation. They assume that while a worker's transition rate from unemployment to employment is endogenously determined through a matching market, employed workers lose their jobs due to exogenous separation shocks and thus a transition rate from unemployment to employment is exogenous. However, recent empirical studies demonstrate that unemployment dynamics is determined by both inflow and outflow rates of unemployment, and find large variations in both inflow and outflow rates over business cycles (Elsby et al., 2009; Fujita and Ramey, 2009). ${ }^{1}$ This suggests that taking into account both hiring and firing margins is important to study effects of fiscal policies on unemployment.

This paper re-visits effects of fiscal policies on unemployment and employment by focusing on both hiring and firing margins. We first provide evidence that an increase in government spending increases the job finding rate and reduces the separation rate, lowering the unemployment rate in the U.S. by using a structural VAR model. We then develop a DSGE model with search frictions in which workers' transition between employment and unemployment are endogenously determined. Our model captures the empirical pattern of responses of the job finding, separation, and unemployment rates to a government spending shock.

The predictions of our model are in contrast with earlier studies that assume exogenous job separation. First, while both models with and without endogenous separation generate a similar pattern of responses of unemployment to a positive government spending shock, the model with endogenous separation generates a larger impact of the shock on unemployment than the model without endogenous separation. The magnitude in our model is much closer to the data than one obtained in the model without endogenous separation. Second, while a positive government spending shock increases vacancies in the model without endogenous separation, it reduces vacancies in the model with endogenous separation. Since an increase in government spending increases vacancies in the data, our model fails to capture the empirical pattern of responses of vacancies.

The different responses in the model economies with and without endogenous separation

\footnotetext{
${ }^{1}$ Recently, several studies investigate the contribution of inflow and outflows rates to the unemployment variability over the business cycle. For the United States, Hall (2005) and Shimer (2012) claim that the outflow rate dominates and the inflow rate is acyclical. In contrast, Elsby et al. (2009) and Fujita and Ramey (2009) find a greater role for inflow rates that account for around half of cyclical changes in unemployment. For European countries, Petrongolo and Pissarides, (2008) and Elsby et al. (2009) find approximately a 50:50 inflow/outflow split to unemployment variation.
} 
are the consequence of both i) the relatively large responsiveness of the separation margin and ii) the feed-back effect of job separation on job creation. In the model with endogenous separation, a positive government spending shock substantially reduces the number of job seekers by lowering job separation, which in turn makes vacancy positing less attractive. However, the reduction in separation is large enough to compensate the reduction in job creation and thus reduces unemployment.

We also study the effect of fiscal stimulus in form of hiring subsidies on the labor market. ${ }^{2}$ The most striking finding is that the effect of increases in hiring subsidies on unemployment differs between models with and without endogenous separation. While a positive hiring subsidy shock reduces unemployment in the model without endogenous separation, it increases unemployment in our model. When a hiring subsidy increases, the cost of positing vacancies falls. A decrease in vacancy cost has two counteracting effects on unemployment in our model. On one hand, it increases firms' incentive to post vacancies, leading to a lower unemployment. On the other hand, it induces more separation by reducing the opportunity cost of continuing existing matches. Under the plausible parameter values, the latter effect dominates the former one. As a result, a positive hiring subsidy shock increases unemployment.

Our work is related to a number of recent papers that study effects of fiscal policies on the labor market. Conventional wisdom says that an increase in government expenditures reduces the unemployment rate. Monacelli et al. (2010) estimate a structural VAR model and obtain a similar conclusion for the U.S. They also demonstrate that a New Keynesian model (NKM) with search frictions is able to match their empirical observations. In contrast, Yuan and Li (2000) estimate an alternative VAR model still with U.S. data and obtain the opposite result that an increase in government expenditures reduces employment. To interpret their findings, they build and estimate a real business cycle model with search frictions and extensive and intensive margins. Brückner and Pappa (2012) estimate a VAR with data from several OECD countries and show that in most cases, an increase in government spending increases the unemployment rate. They build a NKM with search frictions and workers' participation choices to reproduce the data. None of these papers considers hiring subsidy and endogenous job separation.

By considering hiring subsidies, this paper is close to Campolmi et al. (2011) and Faia et al. (2013). To study the effects of hiring subsidies, Campolmi et al. (2011) develop a NKM with search frictions and endogenous participation, assuming job separation is exogenous. Thus, our paper can be viewed as a complement to Campolmi et al. (2011). Faia et al. (2013) also analyze the role of hiring subsides in a NKM model with screening mechanism of heterogeneous workers, which delivers endogenous separation. The main difference between Faia et al. (2013)

\footnotetext{
${ }^{2}$ Most of the stimuli policies undertaken in the aftermath of the Great Recession took the form of labor market subsides. Those expenditures indeed account for 50 to $80 \%$ of the total fiscal stimuli depending on countries. An important example is the HIRE Act and the American Job Act which focused almost entirely on introducing hiring subsidies.
} 
and our paper is that they consider a firing cost that dampens the increase of the job separation rate following an increase in hiring subsidies.

The remainder of the paper is organized as follows. In Section 2, we study effects of a government spending shock on the U.S. labor market by using a structural VAR model. Section 3 describes the theoretical model. We develop a DSGE model with labor market frictions and endogenous job separation. In Section 4, we calibrate the model parameters and present the quantitative results of effects of a government spending shock on the economy. Section 5 studies the effect of a hiring subsidy shock on the economy. We also discuss the unemployment multipliers for both government spending and hiring subsidy shocks. Section 6 concludes.

\section{Empirical evidence}

This section empirically examines the effects of a government spending shock on the U.S. labor market by using a structural vector autoregressive (SVAR) model. Following Blanchard and Perotti (2002), we identify the government spending shock by assuming that government spending is not contemporaneously affected by all variables in the model. ${ }^{3}$ This identification scheme is implemented by ordering government spending first in a SVAR model and using a Choleski decomposition.

We consider a SVAR model consisting of ten variables: real per-capita government spending, real per-capita gross domestic product (GDP), real per-capita private consumption, the nominal interest rate on 3-month T-bills, hours worked per worker, the real wage, the unemployment rate, the vacancy rate, the job finding rate, and the separation rate. Variables not expressed as a rate are logged.

We obtain quarterly data on government spending, GDP, private consumption, the nominal interest rate from the Federal Reserve Economic Data. The real wage is obtained by dividing compensation per hour from the BLS by the GDP deflator. Hours worked per worker are obtained by dividing hours of all persons by the civilian noninstitutional population. The unemployment rate is the quarterly average of seasonally adjusted monthly data constructed by the BLS from the Current Population Survey (CPS). The vacancy rate is constructed from a composite Help-Wanted Index of Barnichon (2010). ${ }^{4}$ The job finding and separation rates are constructed from the CPS short-term unemployment rate and the CPS unemployment data by using the method of Shimer (2012).

\footnotetext{
${ }^{3}$ Monacelli et al. (2010) and Brückner and Pappa (2012) use this identification approach to investigate the effect of government spending on the labor market. Gali et al. (2007) and Perotti (2007) also use the restriction that government spending does not contemporaneously react to changes in macroeconomic variables to identify fiscal shocks.

${ }^{4}$ Barnichon (2010) builds a vacancy positing index that captures the behavior of total "print" and "online" helpwanted advertising, by combining the print-Help-Wanted Index and the online- Help-Wanted Index. We thank Regis Barnichon for generously sharing his data with us.
} 
The sample covers 1954:4-2013:2. The lag length of the SVAR model is based on information criteria and set equal to two. In addition to a constant term, the SVAR model includes a deterministic time trend up to the second order. Following Monacelli et al. (2010), we also include lags 0-4 of each of each of three dummy variables, taking values of 1 on each of the three "Ramey-Shapiro" war dates in our sample.

Figure 1 shows that the impulse responses of the relevant variables to the government spending shock with $95 \%$ confidence bands constructed by the bootstrap method. The shock to government spending is normalized to 1 percentage point of GDP. We show the impulse response functions for a horizon of 20 quarters.

Following the government spending shock, both GDP and consumption rise with peak responses at about 1.6 and 1.0 percent, respectively, after three years. Both responses are statistically significant at the 95 percent confidence level. An increase in government spending increases the real wage. The real wage increases by about 0.8 percent after one and half year and returns to trend very slowly. The hours worked per worker does not change significantly. The responses of output, private consumption, the real wage, and hours worked per worker are broadly consistent with what previous studies found (See for example, Monacelli et al. (2010)).

We now turn to see the effects of the government spending shock on labor market variables. The positive government spending shock reduces the unemployment rate and increases the vacancy rate significantly. The unemployment rate decreases by about 0.37 percentage points at the peak, and the vacancy rate increase by about 0.51 percentage point at the peak.

Since unemployment dynamics are determined by the underlying flows in and outs of unemployment, we now study the responses of the job finding rate and the separation rate to the government spending shock. The positive government spending shock increases the job finding rate and reduces the separation rate significantly. The job finding rate rises by about 2.0 percentage points at the peak after 3 years. The separation rate falls by about 0.1 percentage points at the peak after 11 quarters. The responses of the job finding and separation rates are consistent with the response of the unemployment rate to the government spending shock.

\section{The model}

Empirical evidence suggest that both hiring and firing margins play an important role when we study the effect of a government spending shock on unemployment. This section presents a dynamic stochastic general equilibrium model with labor market frictions in which job separation is endogenously determined. ${ }^{5}$ By using this model, we consider the effects of fiscal stimuli, in

\footnotetext{
${ }^{5}$ Andolfatto (1996) and Merz (1995) consider a stochastic real business cycle model with search frictions and exogenous job separation. Den Hann et al. (2000) develop a dynamic general equilibrium model with search frictions and endogenous job separation and study propagation of aggregate shocks. While they focus on cyclical behavior of labor market variables, this paper studies effects of fiscal stimuli on the labor market.
} 
the form of government spending and hiring subsidies, on the economy.

Environment An economy includes households, firms and the government. Each household consists of a continuum of infinitely-lived members normalized to one. They search for jobs when unemployed, while they supply labor services and earn wages when employed. Firms hire workers in a frictional labor market and produce outputs by using capital and labor. Firms sell their products to households in a competitive market. Employment is the outcome of workers' and firms' search behavior, while wages and labor supply are outcome of a bargaining process. Time is discrete.

In our model, job separation is endogenously determined. Jobs differ by idiosyncratic cost of a non-productive intermediate input which we call an operating cost. When the cost is too high, production is not profitable. Thus, a firm-worker pair chooses a reservation cost and destroys the job whose cost rises above it. ${ }^{6}$

Firm's problem Production takes place when one firm is matched with one worker. When a firm hires a worker, the firm produces output according to a constant-returns-to-scale production function $y_{t}=A_{t} f\left(k_{t}, h_{t}\right)$, where $A_{t}$ is an aggregate productivity common to all firms, $k_{t}$ is capital per worker, and $h_{t}$ is hours worked per worker.

We assume that in order to produce output, a firm-worker pair needs to pay an operating $\operatorname{cost} x_{t}$ besides labor and capital renting costs. The operating cost is idiosyncratic to each match. The match-specific operating cost $x_{t}$ is assumed to be independent and identically distributed across firms and time, with a cumulative distribution function $\Gamma:[\underline{x}, \bar{x}] \rightarrow[0,1]$. Every period an existing match draws a new idiosyncratic cost and decides whether producing output at the new level of cost or terminating the employment relationship. Each match chooses a reservation value $\tilde{x}$; if the match-specific cost falls below $\tilde{x}$, they continue producing output.

Besides endogenous separation, a match might be terminated for an exogenous reason in any given period. Let $\rho^{x}$ denote the probability of exogenous separation, which is assumed to be independent of the idiosyncratic cost, $x$. When job separation, either endogenously or exogenously, occurs, production does not take place and the firm can either reopen a job as a new vacancy or withdraw from the labor market, while the worker becomes unemployed. ${ }^{7}$

Labor market The labor market is subject to frictions in which firms and workers cannot meet instantaneously but must go through a time-consuming search process. The labor market is

\footnotetext{
${ }^{6}$ We incorporate endogenous separation by having idiosyncratic additive operational costs as opposed to multiplicative idiosyncratic productivity as seen in Mortensen and Pissarides (1994). This is because multiplicative idiosyncratic productivity would lead to heterogeneity in hours per worker across matches, while the additive idiosyncratic operational cost leads to homogenous hours across matches.

${ }^{7}$ Note that in equilibrium firms are indifferent between these two options due to free entry.
} 
modeled in the style of a search and matching model developed by Mortensen and Pissarides (1994). The number of successful job matches is determined by the matching function $m_{t}=$ $m\left(u_{t}, v_{t}\right)$, where $u_{t}$ is unemployed workers searching jobs in the period $t$, and $v_{t}$ is number of vacancies posted. The matching function is continuous, twice differentiable, increasing in its arguments, and exhibits constant returns to scale. The probability of a firm with a vacancy being matched with a worker is given by $m\left(u_{t} / v_{t}, 1\right) \equiv q\left(\theta_{t}\right)$, where $\theta_{t} \equiv v_{t} / u_{t}$ is labor market tightness. Then, the probability that an unemployed worker is matched with a firm with a vacant job is $m\left(1, v_{t} / u_{t}\right)=\theta_{t} q\left(\theta_{t}\right)=p\left(\theta_{t}\right)$. Note that both firms and workers take $q_{t}$ and $p_{t}$ as given. It is assumed that workers and firms that are matched in the period $t$ begin active employment relationship at the beginning of the period $t+1$.

Timing of the model The timing of the model is as follows. At the beginning of each period, every firm with a filled job draws an idiosyncratic cost and observes whether or not an exogenous separation shock hits the job. After observing all the shocks in the period, the firm-worker pair may choose to separate endogenously. If either exogenous or endogenous separation takes place, the firm-worker pair does not produce anything in the period. After job separation occurs, the levels of employment and unemployment are determined. At the point, matched firms start production, and unemployed workers search for jobs. At the end of the period, wages are paid and the firm's profits are distributed to the households, and households make consumption decision.

Household's problem A representative household consists of a continuum of individuals of mass one. A member of the household is either employed or unemployed. In the period $t$, a fraction $n_{t}$ of the household's members are employed, and a fraction of $u_{t}$ are unemployed. Following Merz (1995), we assume that family members perfectly insure each other against fluctuations in consumption.

The household's expected life time utility is given by

$$
\mathbb{E}_{0} \sum_{t=0}^{\infty} \beta^{t}\left[\frac{C_{t}^{1-\sigma}}{1-\sigma}-\Phi_{0} n_{t} \frac{h_{t}^{1+\mu}}{1+\mu}\right],
$$

where $\beta \in(0,1)$ is the household's subjective discount factor, $C_{t}$ is consumption of the household, and $h_{t}$ is the individual hours worked. $\Phi_{0}>0$ measures the disutility of working, $\mu$ is the inverse of the Frisch elasticity of labor supply, and $1 / \sigma$ is the intertemporal elasticity of substitution.

Employed household members earn wage, and unemployed household members receive unemployment benefits $z$ from the government. The household receives profits $\Pi$ from firms and pays lump sum taxes $\tau$ to the government. The household may either consume $C$ or accumulate capital $K$ through investment $I$ according to $K_{t+1}=(1-\delta) K_{t}+I_{t}$, where $\delta$ is the 
depreciation rate.

The budget constraint of the representative household is

$$
C_{t}+K_{t+1}+\tau_{t}=\bar{W}_{t}+u_{t} z+(1-\delta) K_{t}+r_{t} K_{t}+\Pi_{t}
$$

where $r_{t}$ denotes the real rental rate of capital and $\bar{W}$ is the total wage income for the household, which will be explained latter.

The household chooses $C_{t}$ and $K_{t+1}$ to maximize (1) subject to its budget constraint. Let $\lambda_{t}$ be the Lagrange multiplier on the budget constraint. Then, the household's problem yields following first-order conditions:

$$
\begin{aligned}
C_{t}^{-\sigma} & =\lambda_{t} \\
\lambda_{t} & =\beta \mathbb{E}_{t} \lambda_{t+1}\left(1-\delta+r_{t+1}\right) .
\end{aligned}
$$

Value functions The problems of firms and workers are characterized by the Bellman equations. The value of a filled job with an idiosyncratic operating $\operatorname{cost} x_{t}, \mathcal{J}_{t}\left(x_{t}\right)$, satisfies

$$
\begin{aligned}
\mathcal{J}_{t}\left(x_{t}\right)= & \max _{k_{t}}\left\{A_{t} f\left(k_{t}, h_{t}\right)-w_{t}\left(x_{t}\right) h_{t}-r_{t} k_{t}-x_{t}+\mathbb{E}_{t} \beta_{t}\left[\left(1-\rho^{x}\right) \int_{\underline{x}}^{\tilde{x}_{t+1}} \mathcal{J}_{t+1}\left(x_{t+1}\right) d \Gamma\left(x_{t+1}\right)\right.\right. \\
& \left.\left.+\left[1-\left(1-\rho^{x}\right) \Gamma\left(\tilde{x}_{t+1}\right)\right] \mathcal{V}_{t+1}\right]\right\},
\end{aligned}
$$

where $\beta_{t}=\beta \lambda_{t+1} / \lambda_{t}$ is the stochastic discount factor, $w_{t}\left(x_{t}\right)$ is wage paid to the employee, and $\mathcal{V}$ is the value of a firm with a vacant job. The value $\mathcal{J}_{t}\left(x_{t}\right)$ is determined by several factors. During the current period, a firm with a filled job produces $A_{t} f\left(k_{t}, h_{t}\right)$, and pays wages $w_{t}\left(x_{t}\right) h_{t}$, the rental cost of capital $r_{t} k_{t}$, and the operating cost $x_{t}$. In the following period, if the match is not destroyed by an exogenous shock and if the idiosyncratic cost is below the reservation value $\tilde{x}_{t+1}$, the match continues and obtains $\mathcal{J}_{t+1}\left(x_{t+1}\right)$; otherwise, the match is destroyed and the firm gets the value of posting a vacancy $\mathcal{V}_{t+1}$.

The first-order condition for the capital is

$$
A_{t} f_{k}\left(k_{t}, h_{t}\right)=r_{t} .
$$

This implies that the optimal capital is chosen to equate the marginal product of capital to the capital rental rate.

The value of a firm with a vacant job is

$$
\mathcal{V}_{t}=-\left(1-\tau_{t}^{v}\right) \gamma+\mathbb{E}_{t} \beta_{t}\left\{q_{t}\left(1-\rho^{x}\right) \int_{\underline{x}}^{\tilde{x}_{t+1}} \mathcal{J}_{t+1}\left(x_{t+1}\right) d \Gamma\left(x_{t+1}\right)+\left[1-q_{t}\left(1-\rho^{x}\right) \Gamma\left(\tilde{x}_{t+1}\right)\right] \mathcal{V}_{t+1}\right\},
$$

where $\gamma$ is a flow cost of posting a vacancy, and $\tau_{t}^{v}$ is a subsidy to the cost of posting the vacancy. ${ }^{8}$

\footnotetext{
${ }^{8}$ As Campolmi et al. (2011) suggested, fiscal stimuli have taken various forms in practice. In the aftermath of the 2007-2008 crisis, expansionary fiscal package implemented in various countries were largely devoted to facilitate job creation. The American Jobs Act passed by the Obama administration is an example. Following Campolmi et al. (2011), we incorporate subsidies to the cost of positing vacancies in order to study effects of fiscal policies targeted particularly at the labor market.
} 
In equilibrium, all profit opportunities from new jobs are exploited, so that the following free entry condition holds:

$$
\mathcal{V}_{t}=0
$$

Total profits of firms in the economy are defined as follows:

$$
\Pi_{t}=\left[A_{t} f\left(k_{t}, h_{t}\right)-r_{t} k_{t}\right] n_{t}-\bar{x}_{t}-\bar{W}_{t}-\left(1-\tau_{t}^{v}\right) \gamma v_{t},
$$

where $\bar{x}_{t}=\frac{n_{t}}{\Gamma\left(\tilde{x}_{t}\right)} \int_{\underline{x}}^{\tilde{x}_{t}} x d \Gamma(x)$ is total operating costs. Total wages paid to the workers are defined as the average wage, conditional on working, times the number of employed workers and working hours. Thus,

$$
\bar{W}_{t}=\frac{n_{t} h_{t}}{\Gamma\left(\tilde{x}_{t}\right)} \int_{\underline{x}}^{\tilde{x}_{t}} w_{t}\left(x_{t}\right) d \Gamma(x) .
$$

We now turn to the worker's side. The value of an employed worker in a job with idiosyncratic cost $x_{t}, \mathcal{W}_{t}\left(x_{t}\right)$, is characterized by the following Bellman equation:

$$
\begin{aligned}
\mathcal{W}_{t}\left(x_{t}\right)= & w_{t}\left(x_{t}\right) h_{t}-\frac{\Phi\left(h_{t}\right)}{\lambda_{t}}+\mathbb{E}_{t} \beta_{t}\left\{\left(1-\rho^{x}\right) \int_{\underline{x}}^{\tilde{x}_{t+1}} \mathcal{W}_{t+1}\left(x_{t+1}\right) d \Gamma\left(x_{t+1}\right)\right. \\
& \left.+\left[1-\left(1-\rho^{x}\right) \Gamma\left(\tilde{x}_{t+1}\right)\right] \mathcal{U}_{t+1}\right\}
\end{aligned}
$$

where $\mathcal{U}$ is the value of an unemployed worker and $\Phi\left(h_{t}\right) / \lambda_{t}=\Phi_{0} h_{t}^{1+\mu} / \lambda_{t}(1+\mu)$ is the disutility from supplying labor in terms of consumption. The value of an employed worker is composed of the wage, the disutility from supplying labor, and the continuation value, which is the value of being employed if the match is not destroyed, or the value of being unemployed if it is destroyed.

The value of an unemployed worker is

$$
\mathcal{U}_{t}=z+\mathbb{E}_{t} \beta_{t}\left\{p_{t}\left(1-\rho^{x}\right) \int_{\underline{x}}^{\tilde{x}_{t+1}} \mathcal{W}_{t+1}\left(x_{t+1}\right) d \Gamma\left(x_{t+1}\right)+\left[1-p_{t}\left(1-\rho^{x}\right) \Gamma\left(\tilde{x}_{t+1}\right)\right] \mathcal{U}_{t+1}\right\} .
$$

An unemployed worker receives the unemployment benefit $z$, and matched with a firm with a vacant job with probability $p_{t}$. If the match is not destroyed by the exogenous shock and the idiosyncratic cost for the match is below the reservation value $\tilde{x}_{t+1}$, the worker will be employed in the following period and obtain the value of being employed; otherwise, she remains unemployed and obtains the value of being unemployed.

Wage determination and hours choice Wages and hours worked are determined as the outcome of a bilateral bargaining process between workers and firms. In each period, firms and workers negotiate through Nash bargains. Thus, wage and hours worked are chosen to maximizes the Nash product

$$
\max _{w_{t}\left(x_{t}\right), h_{t}}\left(\mathcal{W}_{t}\left(x_{t}\right)-\mathcal{U}_{t}\right)^{\eta}\left(\mathcal{J}_{t}\left(x_{t}\right)-\mathcal{V}_{t}\right)^{1-\eta}
$$


where $\eta \in(0,1)$ denotes a worker's bargaining power.

The first-order conditions with respect to $w(x)$ and $h$ yield the wage equation

$$
w_{t}\left(x_{t}\right) h_{t}=\eta\left[A_{t} f\left(k_{t}, h_{t}\right)-x_{t}-r_{t} k_{t}+\left(1-\tau_{t}^{v}\right) \gamma \theta_{t}\right]+(1-\eta)\left(\frac{\Phi\left(h_{t}\right)}{\lambda_{t}}+z\right),
$$

and the hours supply equation

$$
A_{t} f_{h}\left(k_{t}, h_{t}\right)=\frac{\Phi^{\prime}\left(h_{t}\right)}{\lambda_{t}}
$$

The wage equation is similar to the one in the typical search-and-matching model. ${ }^{9}$ The wage is a weighted average of the marginal revenue product and the cost of replacing the worker, and the outside option of the worker, which consists of unemployment benefits and the marginal disutility of labor. The hours supply equation states that hours worked is determined by equalizing the marginal product of hours and the worker's marginal rate of substitution between leisure and consumption.

Job separation and creation A match is destroyed when the idiosyncratic cost is so high that it makes the match surplus to zero. Let $\mathcal{S}(x)$ be the joint gross return from a match with idiosyncratic cost $x$. Then, the match surplus function is given by

$$
\mathcal{S}_{t}\left(x_{t}\right)=\mathcal{J}_{t}\left(x_{t}\right)+\mathcal{W}_{t}\left(x_{t}\right)-\mathcal{U}_{t}-\mathcal{V}_{t}
$$

Using equations (4), (7), (8), and (11) with the free entry condition, we obtain

$$
\begin{aligned}
\mathcal{S}_{t}\left(x_{t}\right)= & A_{t} f\left(k_{t}, h_{t}\right)-x_{t}-r_{t} k_{t}-\frac{\Phi\left(h_{t}\right)}{\lambda_{t}}-z \\
& +\mathbb{E}_{t} \beta_{t}\left(1-p_{t} \eta\right)\left(1-\rho^{x}\right) \int_{\underline{x}}^{\tilde{x}_{t+1}} \mathcal{S}_{t+1}\left(x_{t+1}\right) d \Gamma\left(x_{t+1}\right) .
\end{aligned}
$$

Since the surplus function $\mathcal{S}_{t}\left(x_{t}\right)$ is strictly decreasing in $x_{t}$, the firm and the worker choose a reservation policy, i.e., they will continue their match if $\mathcal{S}_{t}\left(x_{t}\right) \geq 0$ but stop if $\mathcal{S}_{t}\left(x_{t}\right)<0$. Thus, separation takes place at $x_{t} \geq \tilde{x}_{t}$, where $\tilde{x}_{t}$ is defined by $\mathcal{S}_{t}\left(\tilde{x}_{t}\right)=0$. Note that the reservation value at the time the match is formed is the same as the one at match dissolution.

Evaluating (12) at $x_{t}=\tilde{x}_{t}$, we obtain the expression for the reservation threshold:

$$
A_{t} f\left(k_{t}, h_{t}\right)-\tilde{x}_{t}-r_{t} k_{t}+\mathbb{E}_{t} \beta_{t}\left(1-p_{t} \eta\right)\left(1-\rho^{x}\right) \int_{\underline{x}}^{\tilde{x}_{t+1}} \mathcal{S}_{t+1}\left(x_{t+1}\right) d \Gamma\left(x_{t+1}\right)=z+\frac{\Phi\left(h_{t}\right)}{\lambda_{t}} .
$$

We refer to this as the job destruction condition. The left-hand side of (13) is the marginal value of job continuation under the reservation value $\tilde{x}$. The first three terms represent the current productivity gain, and the fourth term is the option value of retaining an existing job. On the right-hand side of (13) is the marginal value of destruction (or the marginal opportunity cost of

\footnotetext{
${ }^{9}$ See, for example, Mortensen and Pissarides (1994) and Pissarides (2000).
} 
continuation) of a job. The job destruction condition says that the optimal reservation value $\tilde{x}$ should be set so as to equalize marginal benefit of continuation and destruction of the job.

By using (4), (6) and the free entry condition, we have the following job creation condition:

$$
\begin{aligned}
\frac{\left(1-\tau_{t}^{v}\right) \gamma}{q_{t}}= & \left(1-\rho^{x}\right) \mathbb{E}_{t} \beta_{t} \int_{\underline{x}}^{\tilde{x}_{t+1}}\left[A_{t+1} f\left(k_{t+1}, h_{t+1}\right)-x_{t+1}-w_{t+1}\left(x_{t+1}\right) h_{t+1}-r_{t+1} k_{t+1}\right. \\
& \left.+\left(1-\tau_{t+1}^{v}\right) \gamma / q_{t+1}\right] d \Gamma\left(x_{t+1}\right) .
\end{aligned}
$$

The job creation condition states that expected cost of positing a vacancy, the left-hand side of (14), is equal to the firm's share of the expected new surplus from a new job match, the righthand side of (14).

Labor market dynamics Let $N_{t}$ be the number of employed workers at the beginning of the period $t$. Then, the evolution of $N_{t}$ is given by

$$
N_{t+1}=\left(1-\rho^{x}\right) \Gamma\left(\tilde{x}_{t}\right) N_{t}+m_{t}=n_{t}+m_{t} .
$$

Note that due to endogenous and exogenous separation, the number of employed workers who produce output in the period $t$ is $n_{t}=\left(1-\rho^{x}\right) \Gamma\left(\tilde{x}_{t}\right) N_{t}$.

The number of unemployed workers is determined by

$$
u_{t}=1-\left(1-\rho^{x}\right) \Gamma\left(\tilde{x}_{t}\right) N_{t}=1-n_{t} .
$$

The job finding rate and the separation rate are given by $p_{t}$ and $\rho^{x}+\left(1-\rho^{x}\right)\left(1-\Gamma\left(\tilde{x}_{t}\right)\right)$, respectively.

Government policy and resource constraint The government finances government spending $G_{t}$, unemployment benefits $u_{t} z$, and the subsidy to the cost of posting the vacancy $\tau_{t}^{v} \gamma v_{t}$ by imposing the lump-sum tax $\tau_{t}$ to households. The government budget constraint is thus given by

$$
\tau_{t}=G_{t}+u_{t} z+\tau_{t}^{v} \gamma v_{t} .
$$

The government spending, $G_{t}$, follow the exogenous stochastic processes:

$$
\log \left(G_{t}\right)=\left(1-\rho_{G}\right) \log \left(G^{*}\right)+\rho_{G} \log \left(G_{t-1}\right)+\varepsilon_{G, t}
$$

where $\varepsilon_{G, t}$ is i.i.d. innovation and $G^{*}$ denotes the steady-state government spending. Similarly, a hiring subsidy takes the following form:

$$
\log \left(\tau_{t}^{v}\right)=\left(1-\rho_{\tau^{v}}\right) \log \left(\tau^{v *}\right)+\rho_{\tau^{v}} \log \left(\tau_{t-1}^{v}\right)+\varepsilon_{\tau^{v}, t}
$$

where $\varepsilon_{\tau^{v}, t}$ is i.i.d. innovation and $\tau^{v *}$ denotes the steady-state hiring subsidy. 
Aggregate output and capital are obtained by

$$
\begin{aligned}
Y_{t} & =n_{t} y_{t}, \\
K_{t} & =n_{t} k_{t},
\end{aligned}
$$

respectively.

By combining the household and government budget constraint:

$$
C_{t}+K_{t+1}-(1-\delta) K_{t}+G_{t}+\gamma v_{t}+\bar{x}_{t}=Y_{t}
$$

which implies that aggregate production must equal private and public demand.

Equilibrium A competitive equilibrium is a set of prices $\left\{r_{t}, w_{t}\left(x_{t}\right)\right\}_{t=0}^{\infty}$ and an allocation $\left\{Y_{t}, K_{t+1}, C_{t}, k_{t}, n_{t}, u_{t}, v_{t}, \theta_{t}, \tilde{x}_{t}, h_{t}\right\}_{t=0}^{\infty}$ which satisfy that

(i) agents optimizes, i.e. the household's optimal conditions (2) and (3), value functions and the free entry condition, the capital rental optimal condition (5), the optimal hours condition (10), the wage equation (9), and the job destruction condition (13) are satisfied;

(ii) resource constraint (20), aggregate capital and output equations (18)-(19), and labor equations (15) and (16);

(iii) the government budget constraint (17).

\section{Quantitative analysis}

In this section, we examine the dynamic responses of our model economy to a government spending shock. We first calibrate the model to match several dimensions of the U.S. data. We then solve the model by approximating the equilibrium conditions around a non-stochastic steady state and simulate it. We also assess the contribution of endogenous separation and a flexible intensive margin to our results by examining models without endogenous separation and a flexible intensive margin. This experiment allows us to determine whether or not the results of our model crucially depend on the incorporation of endogenous separation and the flexible intensive margin.

\subsection{Basic calibration}

In order to study effects of fiscal stimulus on labor market variables, we calibrate the model to match certain U.S. economy facts. Specifically, we set the steady-state vacancy-unemployment ratio, the job-finding rate, and the separation rate to the observed average values in the U.S. economy. We choose the model period to be one month. ${ }^{10}$ We set the discount factor $\beta=0.996$

\footnotetext{
${ }^{10}$ As Monacelli et at. (2010) argue, the job finding rate in the US is quite high, so unemployed workers on average find a job within a quarter. In order to capture this feature, we choose to calibrate the model at a monthly frequency.
} 
to match the annual real interest rate of approximately 4 percent. The relative risk aversion parameter $\sigma$ is set to 2 . We calibrate $\Phi_{0}$ such that the implied steady-state value of hours worked is $1 / 3$. We set $\mu=2$ implying the elasticity of intertemporal substitution in the hours supply of 0.5 , which is consistent with evidence for the U.S.

We assume that the matching function is Cobb-Douglas, given by $m\left(u_{t}, v_{t}\right)=m_{0} u_{t}^{\xi} v_{t}^{1-\xi}$, where $m_{0}$ is the matching constant and $\xi$ is the matching elasticity with respect to unemployment. The elasticity parameter $\xi$ is set to 0.5 , as suggested by Petrongolo and Pissarides (2001). We assume that the worker's bargaining power $\eta$ is 0.5 , as has become standard in the literature. This choice also guarantees that Hosios (1990) condition is satisfied.

We target the steady-state vacancy-unemployment ratio to 0.72 , as reported by Pissarides (2009). ${ }^{11}$ Monthly transitions data from Shimer (2005) gives a mean value of 0.594 for the job finding rate and 0.036 for the job separation rate between 1960 and 2004. In order to pin down the scale parameter $m_{0}$, we combine the monthly job finding rate with the vacancyunemployment ratio.

We now turn to parameters related to job separation. Silva and Toledo (2009) use evidence provided by Davis, Faberman, and Haltiwanger (2006) and Nagypál (2004) to determine the exogenous and endogenous components of the separation rate. They assume that endogenous job separation accounts for, on average, 35\% of total separations. Since we target a total separation rate of 0.036 , we set the monthly exogenous separation rate at $\rho^{x}=0.0234$. Following Mortensen and Pissarides (1994), we assume that the idiosyncratic cost distribution $\Gamma$ is uniform in the range $[0, \zeta]$, so that $\Gamma(x)=x / \zeta$. The parameter $\zeta$ is chosen to match the monthly endogenous job separation rate. See Pissarides (2007) and Elsby and Michaels (2008) for the similar calibration strategy.

The production function is specified by $y=A k^{\alpha} h^{1-\alpha}$. We normalize $A=1$ and set the capital share $\alpha=1 / 3$. The standard annual capital depreciation rate is $10 \%$, so we set a value of $\delta$ to $0.1 / 12$ per month. Following Shimer (2005), the vacancy cost $\gamma$ is obtained from the steady-state solutions of the model.

We target the unemployment benefits $z$ to be $40 \%$ of the average wage of employed workers in the economy. ${ }^{12}$ Following Campolmi et al. (2011), we set the steady-state value for govern-

\footnotetext{
${ }^{11}$ The sample mean for the vacancy-unemployment ratio in 1960-2006 is derived by using JOLTS data since December 2000 and the Help-Wanted Index adjusted to the JOLTS units of measurement before then.

${ }^{12}$ This parameter has been the subject of some discussion. Shimer (2005) sets $z / \bar{w}=0.4$, where $\bar{w}$ is the average worker's wage, in order to capture the unemployment benefits. Hagedorn and Manovskii (2008) argue that Shimer's choice of the value of the opportunity cost of employment is too low because it does not allow for the value of leisure, home production, or unemployment benefits. They calibrate the opportunity cost of employment and the worker's bargaining power to match the observed cyclical response of wages and average profit rate. Their results are $z / \bar{w}=0.955$ and $\eta=0.052$. Mortensen and Nagypál (2007) criticize Hagedorn and Manovskii (2008) for using these parameters because these parameters yield workers a gain of $2.8 \%$ inflow utility by going from unemployment to employment. Hall and Milgrom (2008) use the empirical literature on household consumption and labor supply
} 
ment spending to output ration $G / Y=0.15$ and the steady-state level of the hiring subsidy $\tau^{v *}=0.01$. The autocorrelations of government spending $\rho_{G}$ and of the hiring subsidy $\rho_{\tau^{v}}$ are set to $0.9^{1 / 3}$. The parameter values are summarized in Table 1.

Selected endogenous variables in the steady state under the calibrated parameter values are reported in Table 2. Labor market tightness, the job-finding rate, the separation rate are equal to their target values.

\subsection{Effects of a government spending shock}

We now study dynamic responses of the economy to a government spending shock. The solid lines in Figure 2 display impulse responses of relevant variables to an increase in government spending corresponding to 1 percent of steady state output.

An increase in government spending increases output and hours worked per worker. On the impact, both output and hours worked per worker rise and in the following periods, they decrease and gradually return to their steady-state values. A negative wealth effect increases hours worked per worker, leading to higher output that each match produces. Furthermore, as seen below, the increase in government spending raises the employment level, which further increases total output of the economy. The positive government spending shock crowds out private consumption. Thus, the model fails to account for the consumption dynamics in the data. $^{13}$

We now turn to see the dynamic responses of labor market variables to the government spending shock. An increase in government spending leads to a significant fall in the unemployment rate. It also increases the job finding rate and reduces the separation rate. The pattern of responses of these labor market variables to the government spending shock is consistent with the empirical findings in Section 2. However, the model cannot consistently capture the empirical pattern of responses of vacancies. While an increase in government spending increases vacancies in the data, it reduces vacancies in the model.

These movements in labor market variables can be explained as follows. A positive government spending shock induces a negative wealth effect that raises the value of the match's surplus by reducing the value of non-work activity, in particular by reducing the component associated with the disutility from supply hours of work. The higher surplus, shared between the firm and the worker by Nash bargaining, in turn raises job creation and reduces job destruction, when other things equal. However, the reduction in job seekers associated with the lower

\footnotetext{
and estimate the value of $z / \bar{w}=0.71$.

${ }^{13}$ Although our model cannot empirically consistent responses of consumption, the fact that government spending shock crowds out consumption is in line with the prediction of a standard neoclassical model (see, for example, Baxter and King, 1993). The improvement in tracing the actual consumption dynamics is left for our future research. A number of studies consider mechanisms that make consumption responses in theory become consistent with the data. See for example, Gali et al. (2007) and Linnemann (2006).
} 
job separation reduces the probability that a firm with a vacancy finds a worker and thus discourages hiring. Under the baseline calibration, job creation goes down, but the reduction in separation is large enough to reduce unemployment.

While our model can qualitatively capture the empirical pattern of responses of the unemployment, job finding, and separation rates to the government spending shock, it fails to account for the size of the impact of the shock on these variables. In the model, at the peak, unemployment and separation rates fall by about 0.14 percent and 0.32 percent, respectively. In contrast, in our SAVR estimates, they fall by about 0.37 percent and 0.1 percent, respectively. While the job finding rate increases by about 0.18 percent at the peak in the model, it increase by about 2.0 percent in our empirical evidence.

\subsection{The role of endogenous job separation}

The prediction of our model is in contrast with that of a model without endogenous job separation. For comparison, we develop a version of our model in which separation takes place due to only exogenous shocks. We then simulate a quantitative version of the model using our calibration strategy. ${ }^{14}$ The results are also shown in Figure 2.

The striking finding is that the responses of the model economies with and without endogenous job separation are different. First, the pattern of responses of vacancies differs between two models. This can be explained as follows. In the model with endogenous separation, a positive government spending shock can substantially reduce the number of job seekers (unemployed workers) by lowering job separation, which in turn makes vacancy posting less attractive.

Second, the model with endogenous job separation generates a larger impact of the government spending shock on unemployment. In our model, unemployment falls by about 0.14 percent at the peak. On the other hand, it falls by about 0.04 percent at the peak in the model without endogenous separation. This is far below the estimated magnitude in Section 2. In our SAVR estimates, in response to a positive government spending shock, unemployment falls by about 0.37 percent at the peak. Although the magnitude in our model is still short of its estimate, it is much closer than the one obtained in the model without endogenous separation. It is also important to note that the response of the job finding rate in the model with endogenous job separation is smaller than that in the model without endogenous job separation. While the job finding rate increases by about 0.18 percent at the peak in the model with endogenous job separation, it increases by about 0.59 percent at the peak in the model without endogenous job separation. This is because a reduction in job seekers associated with lower job separation discourages hiring and thus reduces the job finding rate in the model with endogenous job separation.

\footnotetext{
${ }^{14}$ It is note that the two economies share the same steady-state values of the vacancy-unemployment ratio, the job-finding rate and the separation rate.
} 


\subsection{Role of intensive margin}

In our model, a baseline transmission mechanism of the government spending shock in the economy is an increase in the value of match's surplus due to the negative wealth effect. The negative wealth effect associated with a rise in government spending reduces the leisure cost of supplying hours of work, increasing the match's surplus. A key to this channel is having adjustment of the labor input at an intensive margin, since this introduces a benefit from being unemployed expressed in leisure gains, which affects the value of the match's surplus.

We now study the role of the intensive margin to our results. In Figure 2, we present the responses of an economy that is otherwise identical to our benchmark model expect for the assumption of the hours worked channel. Specifically, we consider a version of our model with fixed hours worked per worker. The value of hours worked is set to $1 / 3$, the same to our benchmark model.

Qualitatively, the models with and without the hours worked decision display a similar pattern in response to a government spending shock. However, their sizes of impact are different. Figure 2 shows that the responses of labor market variables in our baseline model are smaller than those in the model with fixed hours worked. This is because an increase in the match's surplus due to the negative wealth effect in our baseline model is smaller than that in the model with fixed hours worked. In our baseline model, the negative wealth increases hours worked per worker. This lowers the match's surplus by increasing the disutility from supplying hours of work.

\section{Discussion}

In this section, we first study the effect of a hiring subsidy shock on the labor market variables in the model with endogenous job separation. We then calculate unemployment multipliers for both government spending and hiring subsidy shocks. Finally, we examine how the degree of persistence of a government spending shock affects the model's prediction.

\subsection{The effect of hiring subsidy}

We now study the dynamic responses of our economy to a hiring subsidy shock. Figure 3 shows impulse responses of labor market variables to a one percentage point increase in the subsidy to the cost of posting a vacancy.

An increase in the hiring subsidy leads to higher job creation and higher job separation. The rise in job separation is due to the fact that the hiring subsidy makes separation less costly as it reduces the search cost to be paid to find a new match in the case of separation. In this case, the response of the separation margin reinforces the response of the hiring margin by expanding 
the pool of job seekers. However, under the calibrated parameter values, the increment of job separation exceeds that of job creation, and thus unemployment increases.

In order to assess the contribution of endogenous job separation to our results, we study effects of the hiring subsidy shock in the model without endogenous job separation. Results are also shown in Figure 3.

The most striking finding is that predictions of models with and without endogenous job separation are incompatible with respect to the response of unemployment. The model without endogenous job separation predicts a decreased unemployment in response to the positive hiring subsidy shock, which is opposite to what the model with endogenous job separation predicts.

This difference is the results of incorporating endogenous job separation into the model. The incorporation of endogenous job search gives rise to a new channel through which a positive hiring subsidy shock increases unemployment: an increased separation rate. When the hiring subsidy increases, the cost of positing vacancies falls. A decrease in job creation cost also reduces the opportunity cost of continuation of an existing job. This induces more separation, leading to a higher unemployment.

Equally important, models with and without endogenous separation generate quantitatively different results. Specifically, although both models predict an increase in vacancies in response to positive hiring subsidy shocks, their sizes of the impact differ. While vacancies rise by about 0.15 percent at the peak in the model with endogenous job separation, it rises by about 0.06 percent at the peak in the model with exogenous job separation. Thus, the model with endogenous separation generates a larger impact of the hiring subsidy shock on vacancies than the model without endogenous separation. This is because, in the model with endogenous separation, an increase in unemployment due to the shock expands the number of job seekers and facilitates firms to find workers. This induces more vacancy postings.

\subsection{Fiscal multipliers}

In the literature, some studies argue that hiring subsidies deliver larger multipliers than government spending. However, this result is usually obtained in models without endogenous separation. We now compute unemployment multipliers for both traditional increases in government spending and increases in hiring subsidies in our model, and compare our results with those in the model without endogenous separation.

Following Faia et al. (2013), we compute the net present value fiscal multipliers:

$$
\text { UMulti }_{t, t+j}=\frac{\sum_{i=1}^{j} \beta^{i-1}\left(u_{t+i}-u\right)}{\sum_{i=1}^{j} \beta^{i-1}\left(\Omega_{t+i}-\Omega\right)},
$$

where $\Omega_{t}=G_{t}$ for the government spending multiplier, while $\Omega_{t}=\gamma v \tau_{t}^{v}$ for the hiring subsidy multiplier. The variables without time subscript denote the steady state values of them. 
Figure 4 shows the results. When separation is merely due to exogenous shocks, the unemployment multiplier for hiring subsidies is larger (in absolute value) than that for government spending. This implies that hiring subsidies are more effective than government spending if the fiscal authority is concerned about unemployment. This results is in line with the existing studies, such as Campolmi et al. (2011). However, once the assumption of exogenous separation is relaxed, the prominence of hiring subsidies does not hold anymore. In the model with endogenous separation, an increase in hiring subsidies instead increases unemployment, and thus the unemployment multiplier is positive. On the other hand, as in the model without endogenous separation, a positive government shock reduces unemployment. Therefore, in general, the multiplier for government spending is larger (in absolute value) than that for hiring subsidies.

\subsection{Role of persistence}

We now examine how the degree of persistence of fiscal policies affects models' outcomes. As Faia et al. (2013) argue, although the time series data of government spending is fairly persistent in normal times, the government might use fiscal stimulus in a discretionary and episodic fashion during extreme recessions. Furthermore, Mayer et al. (2010) demonstrate that effect of a government spending shock on the labor market depends on the degree of persistence of the shock in a model without endogenous separation. Thus, it is worth studying how the degree of persistence of fiscal policies affects the labor market in a model with endogenous separation.

Figure 5 displays dynamic responses of labor market variables to a government spending shock for three different values of $\rho_{g}: 0.75^{1 / 3}$ (low), $0.90^{1 / 3}$ (middle), and $0.95^{1 / 3}$ (high). Effects of the government spending shock on labor market variables depend on the degree of persistence. When the shock is short-lived, the size of the impact of the government spending shock on labor market variables becomes smaller.

\section{Conclusion}

Recent empirical studies of the U.S. labor market suggest that in order to study the unemployment dynamics, it is important to take into account both hiring and firing margins. Focusing on both hiring and firing margins, this paper studies the effect of fiscal expansion on the labor market. Our empirical analysis demonstrates that an increase in government spending increases the job finding rate and reduce the separation rate, lowering the unemployment rate. To account for these empirical findings, we develop a dynamic stochastic general equilibrium model with search frictions in which job separation is endogenously determined. We then consider fiscal stimuli in the form of government spending and hiring subsidies. Although our model can generate a similar pattern of responses of the job finding, separation, and unemployment rates to a government spending shock, it fails to account the empirical pattern of responses of vacancies. 
The predictions of our model are in contrast with earlier studies that use models without endogenous job separation. First, our model generates a larger size of the impact of a government spending shock on labor market variables than the model without endogenous job separation. Second, while an increase in hiring subsidies reduces unemployment in models without endogenous job separation, it increases unemployment in our model.

A number of important issues remain for future research. One issue to be considered is a more realistic fiscal setup with distortionary taxes. In our model, the government relies on lump-sum taxes and a balanced budget. It is worth exploring how the economy with a realistic fiscal setup responds to a distortionary fiscal policy, in the form of not just a spending shock but also a tax shock. Also, it is worth considering the role of workers' on-the-job search when we analyze effects of fiscal stimuli on the labor market. Recent empirical studies of the U.S. labor market reveal that a large fraction of worker leavings jobs move to new jobs without intervening unemployment and this job-to-job flow is pro-cyclical (Fallick and Fleishman, 2004; Nagypál, 2004). This fact suggests that in order to study the cyclical behavior of labor market variables, it is necessary to use a model in which workers' transition between employment, unemployment, and across jobs are endogenously determined. Examining the effects of fiscal policies on labor market variables by using a model with on-the-job search is a fruitful avenue for research.

\section{References}

[1] Andolfatto, D., 1996. Business cycles and labor market search. American Economic Review $86,112-132$.

[2] Barnichon, R., 2010. Building a composite Help-Wanted Index. Economics Letters 109, 175178.

[3] Baxter, M., King, R. G., 1993. Fiscal Policy in General Equilibrium. American Economic Review 83(3), 315-34.

[4] Blanchard, O., Perotti, R., 2002. An empirical characterization of the dynamic effects of changes in government spending and taxes on output. Quarterly Journal of Economics 117 (4), 1329-1368.

[5] Brückner, M., Pappa, E., 2012. Fiscal Expansions, Unemployment, and Labor Participation. International Economic Review 53, 1205-1228.

[6] Campolmi, A., Faia, E., Winkler, R., 2011. Fiscal Calculus and the Labor Market. The B.E. Journal of Macroeconomics. Volume 11, Issue 1.

[7] Davis, S. J., Faberman, R. J., Haltiwanger, J. C., 2006. The Flow Approach to Labor Markets: New Data Sources and Micro-Macro Links, NBER Working Paper \#12167. 
[8] Den Haan, W., Ramey, G., Watson, J., 2000. Job Destruction and Propagation of Shocks. American Economic Review 90(3), 482-498.

[9] Elsby, M., R., Michaels., 2008. Marginal Jobs, Heterogeneous Firms, \& Unemployment Flows, NBER Working Paper \#13777.

[10] Elsby, M., Michaels, R., Solon, G., 2009. The Ins and Outs of Cyclical Unemployment. American Economic Journal: Macroeconomics 1 (1), 84-110.

[11] Faia, E., Lechthaler, W., Merkl, C., 2013. Fiscal Stimulus and Labor Market Policies in Europe. Journal of Economic Dynamics and Control 37, 483-499.

[12] Fallick, B., Fleischman, C., 2004. Employer-to-Employer Flows in the U.S. Labor Market: The Complete Picture of Gross Worker Flows. Federal Reserve Board, Finance and Economics Discussion Series Working Paper 2004-34.

[13] Fujita, S., Ramey, G., 2009. The Cyclicality of Separation and Job Finding Rates. International Economic Review 50 (2), 415-430.

[14] Galí J., David Lóez-Salido, J., Vallés, J., 2007. Understanding the effects of government spending on consumption. Journal of the European Economic Association 5 (1), 227-270.

[15] Hagedorn, M., Manovskii, I., 2008. The cyclical behavior of equilibrium unemployment and vacancies revisited. American Economic Review, 98, 1692-1706.

[16] Hall, R. E., 2005. Employment efficiency and sticky wages: evidence from flows in the labor market, Review of Economics and Statistics, 297, 397-407.

[17] Hall, R. E., Milgrom, P., 2008. The Limited Influence of Unemployment on the Wage Bargain. American Economic Review 98, 1653-74.

[18] Hosios, A., 1990. On the Efficiency of Matching and Related Models of Search and Unemployment. Review of Economic Studies 57, 279-298.

[19] Linnemann, L., 2006. The Effect of Government Spending on Private Consumption: A Puzzle? Journal of Money Credit and Banking 38, 1715-1735.

[20] Mayer, E., Moyen, S., Stähler, N., 2010. Government expenditures and unemployment : a DSGE perspective. Discussion paper / Deutsche Bundesbank / Series 1, Economic studies $18 / 2010$.

[21] Merz, M., 1995. Search in the labor market and the real business cycle. Journal of Monetary Economics 36, 269-300. 
[22] Monacelli, T., Perotti, R., Trigari, A., 2010. Unemployment Fiscal Multipliers. Journal of Monetary Economics, 57(5), 531-553.

[23] Mortensen, D. T., Pissarides, C. A., 1994. Job creation and job destruction in the theory of unemployment. Review of Economic Studies 61, 397-415.

[24] Mortensen, D. T., Nagypál, E., 2007. More on Unemployment and Vacancy Fluctuations. Review of Economic Dynamics 10, 327-347.

[25] Nagypál, E., 2004. Worker Reallocation over the Business Cycle: The Importance of Job-toJob Transitions. Mimeo. Northwestern University.

[26] Perotti, R., 2007. In Search of the Transmission Mechanism of Fiscal Policy. NBER Macroeconomics Annual 2007, vol. 22, pp. 169-226.

[27] Petrongolo, B., Pissarides, C. A., 2001. Looking into the Black Box: A Survey of the Matching Function. Journal of Economic Literature 39, 390-431.

[28] Petrongolo, B. and Pissarides, C. A., 2008. The ins and outs of European unemployment. American Economic Review 98, 256-62.

[29] Pissarides, C. A., 2000. Equilibrium Unemployment Theory, second ed. MIT Press, Cambridge, MA.

[30] Pissarides, C. A., 2007. The Unemployment Volatility Puzzle: Is Wage Stickiness the Answer?, CEP Discussion Paper No 839.

[31] Pissarides, C. A., 2009. The unemployment volatility puzzle: is wage stickiness the answer? Econometrica 77, 1339-1369.

[32] Shimer, R., 2005. The cyclical behavior of equilibrium unemployment and vacancies. American Economic Review 95, 25-49.

[33] Shimer, R., 2012. Reassessing the Ins and Outs of Unemployment. Review of Economic Dynamics 15, 127-148.

[34] Silva, J. I., Toledo. M., 2009. Labor Turnover Costs and the Cyclical Behavior of Vacancies and Unemployment. Macroeconomic Dynamics 13, 76-96.

[35] Uhlig, H., 2010. Some Fiscal Calculus. American Economic Review 100(2), 30-34.

[36] Yuan, M., Li, W., 2000. Dynamic employment and hours effects of government spending shocks. Journal of Economic Dynamics and Control 24(8), 1233-1263. 
Table 1: Parameter values

\begin{tabular}{llll}
\hline \hline Parameter & Description & Value & Source/Target \\
\hline$\beta$ & Discount factor & 0.996 & Data \\
$\delta$ & Depreciation rate & $0.1 / 12$ & Data \\
$A$ & Aggregate productivity & 1.0 & Normalization \\
$\alpha$ & Parameter in production function & 0.333 & Data \\
$m_{0}$ & Matching efficiency & 0.70 & Job-finding rate \\
$\xi$ & Matching elasticity & 0.5 & Petrongolo and Pissarides (2001) \\
$\rho^{x}$ & Exogenous separation rate & 0.023 & $65 \%$ of total separations \\
$\zeta$ & The upper support of $\Gamma$ & 0.678 & $35 \%$ of total separations \\
$\sigma$ & Relative risk aversion parameter & 2.0 & See text \\
$\Phi$ & Disutility of labor & 64.31 & Set to target $h=1 / 3$ \\
$\mu$ & Frisch elasticity & 2.0 & See text \\
$z$ & Unemployment benefits & 0.324 & Replacement rate $40 \%$ \\
$\eta$ & Worker's bargaining power & 0.5 & Hosios (1990) condition \\
$\gamma$ & Vacancy cost & 0.134 & $v-u$ ratio \\
$\tau^{v *}$ & Hiring subsidy rate & 0.01 & See text \\
$\rho_{G}$ & Gov. spending autoregressive parameter & $0.9^{1 / 3}$ & See text \\
$\rho_{\tau^{v}}$ & Hiring subsidy autoregressive parameter & $0.9^{1 / 3}$ & See text \\
\hline & & & \\
\hline
\end{tabular}


Table 2: Model solutions

\begin{tabular}{lll}
\hline \hline Variables & Description & Solution \\
\hline$\theta$ & Labor market tightness & 0.72 \\
$\tilde{x}$ & Reservation cost & 0.67 \\
$u$ & Unemployment rate & 0.059 \\
$v$ & Vacancy & 0.042 \\
$n$ & Employment rate & 0.941 \\
$p$ & Job-finding rate & 0.594 \\
- & Separation rate & 0.036 \\
$h$ & Hours worked & 0.333 \\
$C$ & Aggregate consumption & 0.696 \\
$G$ & Government spending & 0.244 \\
$T$ & Lump-sum tax & 0.263 \\
$Y$ & Aggregate output & 1.625 \\
$I$ & Aggregate investment & 0.365 \\
\hline
\end{tabular}



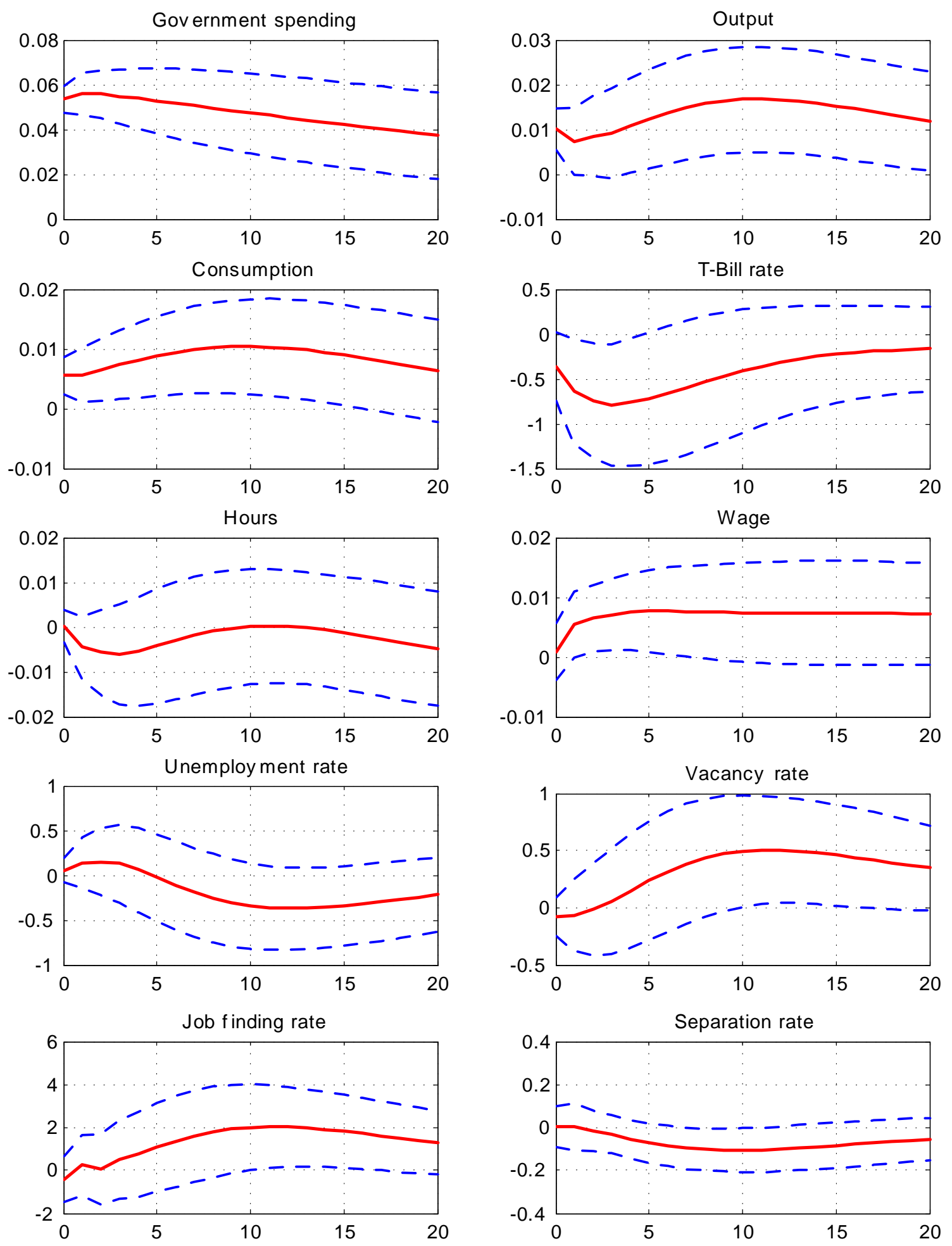

Figure 1: The dynamic effects of a positive government spending shock

Note: The shock to government spending is normalized to one percentage point of GDP. The horizontal axis represents quarters after the shock. Dashed lines indicate the 95 percent confidence bands, constructed by the bootstrap method. Sample period covers 1954:4-2013:2. 

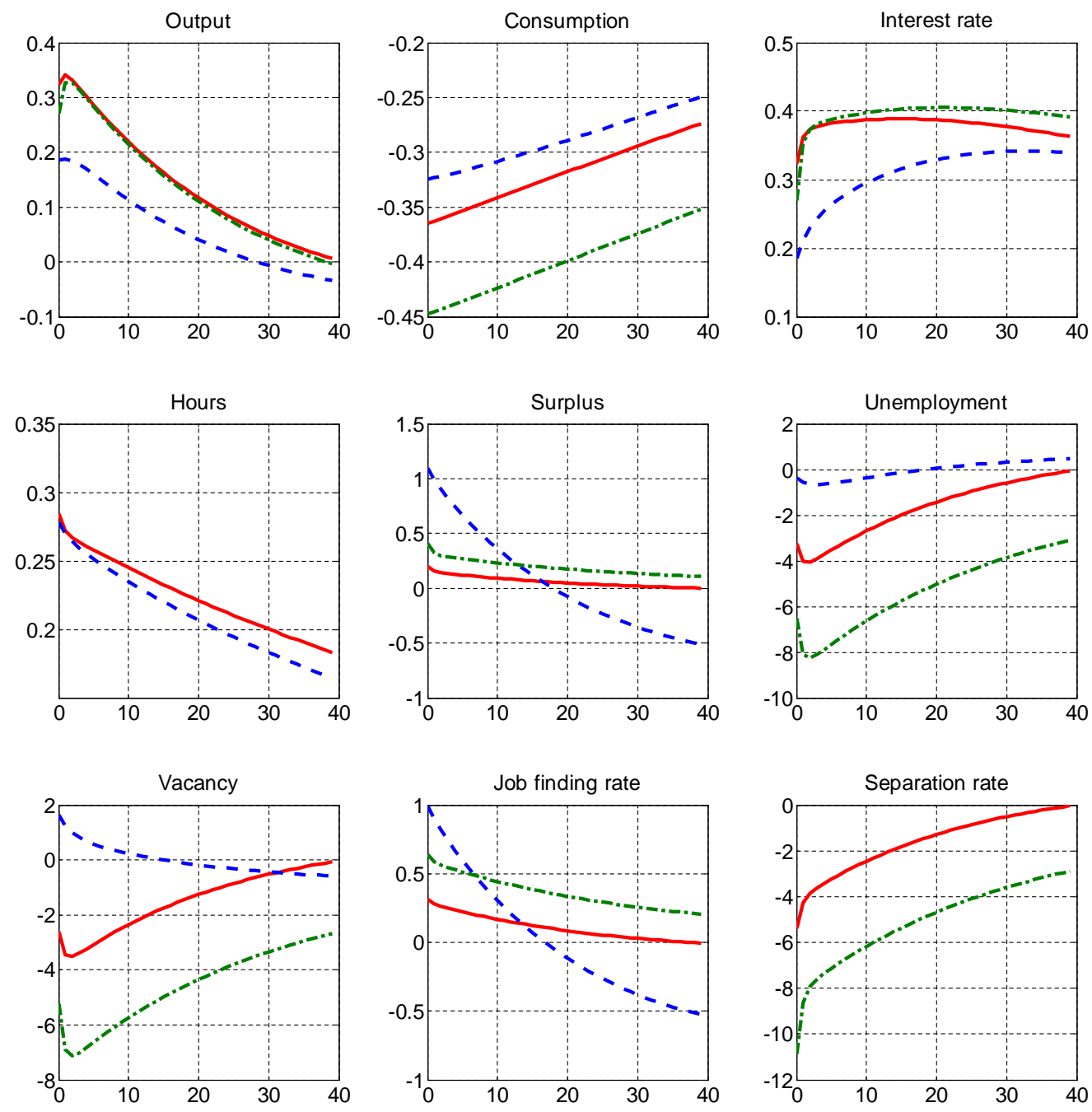

-Endo. Sep. - - Exo. Sep. - - - w/o int. marg.

Figure 2: The solid lines labeled "Endo. Sep" plot the impulse responses to a positive government spending shock in our model. The dashed lines labeled "Exo. Sep" plot the impulse responses in the model without endogenous job separation. The dash-dotted line labeled "w/o int. marg" plot the impulse responses in the model with fixed hours worked $(h=1 / 3)$. The vertical axis represents percentage deviations from the steady-state value of the variable of interest. The horizontal axis represents months after the shock. 

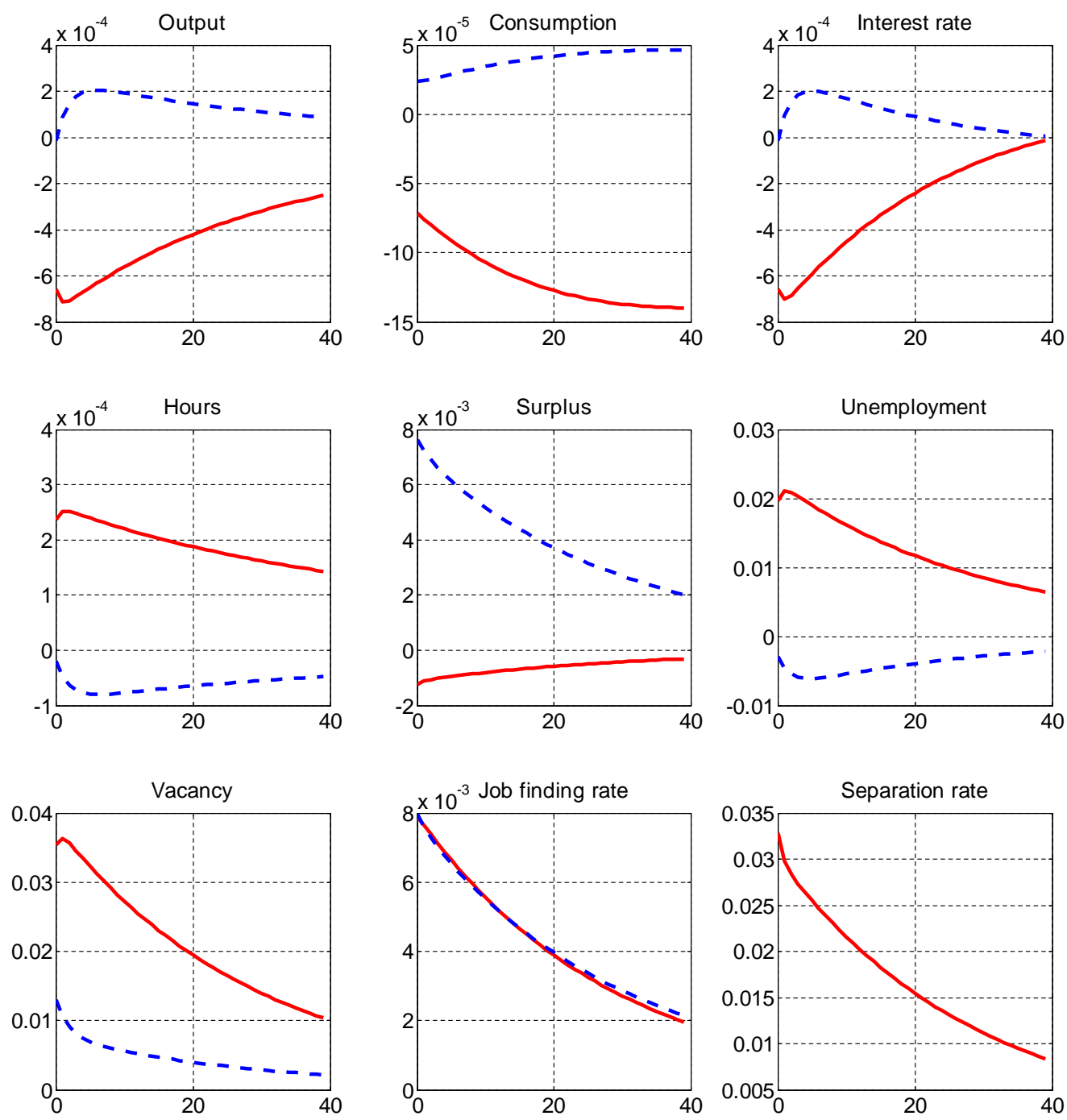

Endo. Sep. - - Exo. Sep.

Figure 3: Responses to a one percentage point increase in the hiring subsidy

Note: The solid lines labeled "Endo. Sep" plot the impulse responses to a positive hiring subsidy shock in our model. The dashed lines labeled "Exo. Sep" plot the impulse responses in the model without endogenous job separation. The vertical axis represents percentage deviations from the steady-state value of the variable of interest. The horizontal axis represents months after the shock. 


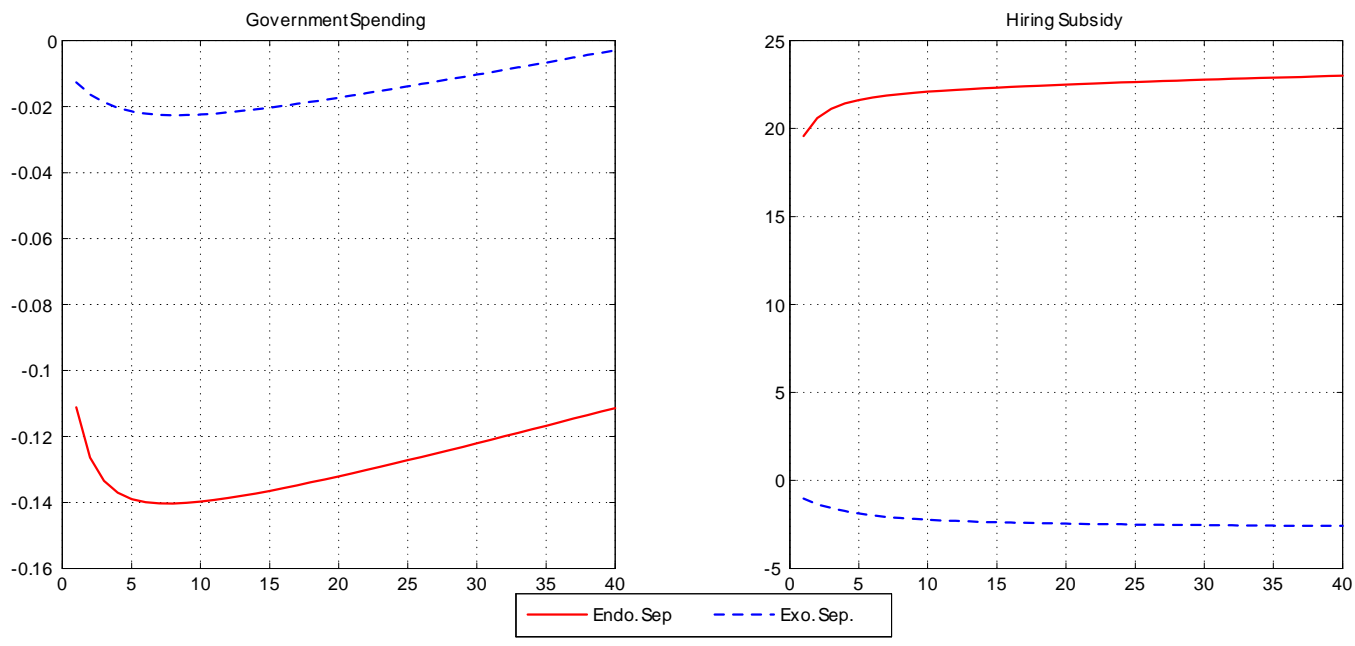

Figure 4: Unemployment multipliers

Note: The solid lines labeled "Endo. Sep" plot the unemployment multipliers in our model. The dashed lines labeled "Exo. Sep" plot the unemployment multipliers in the model without endogenous job separation. The horizontal axis represents months after the shock. 

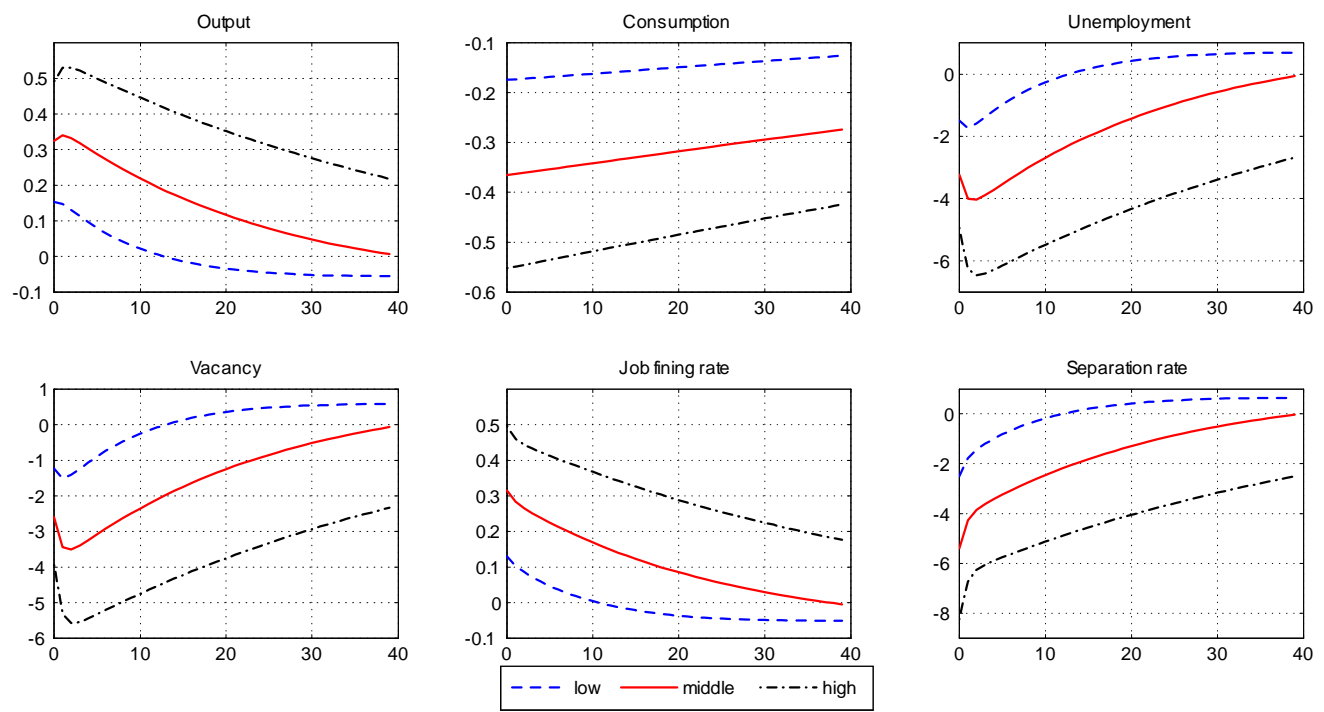

Figure 5: The role of the degree of persistence of government spending shocks

Note: The solid line labeled "middle" plots the impulse response of a variable of interest to a positive government spending shock with $\rho=0.9^{1 / 3}$. The dashed line labeled "low" plots the impulse response to a positive government spending shock with $\rho=0.75^{1 / 3}$. The dash-dotted line labeled "high" plots the impulse response to a positive government spending shock with $\rho=0.95^{1 / 3}$. The horizontal axis represents months after the shock. 